\title{
NONLINEAR WAVE DYNAMICS OF A DISPERSE GRANULAR LAYER STIMULATED BY AN INWARDS MOVING PISTON
}

\author{
Sergiy Mykulyak (D), Sergii Skurativskyi (iD) \\ Subbotin Institute of Geophysics, NAS of Ukraine, \\ 63B, Bohdan Khmelnytskyi St., \\ Kyiv, UA-03142, Ukraine, \\ e-mail: mykulyak@ukr.net
}

(Received 22 April 2020; in final form 15 November 2020; accepted 16 October 2020; published online 16 February 2021)

\begin{abstract}
Three-dimensional simulations of wave propagation in a granular medium layer containing particles with polydisperse size distribution are performed using the discrete element method (DEM). The wave is generated by a piston subjected to an impulse load. It is shown that in the free surface layer, rotation wave structures are formed. Their location, time of occurrence and duration are determined using correlation analysis. These wave structures are revealed when the friction between the grains (particles) is incorporated and, moreover, the gravitation field resulting in the non-uniform distribution of the inter-particle force field is taken into account. The absence of the rotation wave formation is also shown when the inhomogeneity caused by the gravitational field is destroyed by vertical loading.
\end{abstract}

Key words: granular medium, nonlinear waves, rotation wave structure.

DOI: https://doi.org/10.30970/jps.25.1401

\section{INTRODUCTION}

Compared to continuous medium materials, wave propagation processes in granular media are more complex. The complexity stems from several factors such as the discontinuity and heterogeneity of a granular medium, the nonlinear and dissipative character of grain interactions, rotational motion and repacking of grains under deformation, the presence of force chains formed by grains subjected to large loads, to mention a few [1-6]. These features result in interesting phenomena such as the propagation of weak disturbances along the force chains [7-11] and the qualitative change in the wave pattern with an increase in the wave amplitude due to grain repacking $[8,11,12]$, the appearance of a coherent and speckle parts of an acoustic wave [11, 1315], fast high-frequency and slow low-frequency waves under a high-amplitude loading, acoustic emission and characteristic frequencies [16], growth of the sound speed with an increase in pressure [17, 18]. The speed of an acoustic wave depends on the degree of ordering in granular monodisperse system, whereas in a polydisperse system it depends on the dispersion of the grain sizes $[19,20]$. In the case of periodic granular packing, solitary waves can be generated [21-25]. In contrast, the pressure wave loses solitary properties if randomness is introduced into the granular medium, revealing a strong force amplitude decay [26, 27]. Another feature that distinguishes a granular medium from a continuum one, is the existence of the convective movements upon application of vertical vibrations [28-31]. The rotation wave structures also have been found in the simulation of the pressure wave propagation in a granular medium layer experiencing gravitation in a two-dimensional problem statement [32]. This article is devoted to the study of wave structures in a granular medium for a three-dimensional formulation.

\section{THE STATEMENT OF THE PROBLEM}

We consider a three-dimensional wave propagation in a layer of a granular medium in the gravity field (Fig. 1a). The wave is generated by a force applied to the piston in $y$ direction. The upper surface is free and periodic conditions are set on the side walls. The granular medium is formed by $N$ spherical weakly polydisperse grains (particles). The interaction between the grains [32] is described by the Hertz model of elastic bodies with Coulomb's friction. The motion of the $i$ th particle is given by the system of differential equations

$$
m_{i} \frac{d^{2} \mathbf{x}_{i}}{d t^{2}}=\sum_{j} \mathbf{F}_{i j}, \quad I_{i} \frac{d^{2} \boldsymbol{\Phi}_{i}}{d t^{2}}=\sum_{j} \mathbf{M}_{i j}, \quad i=1, \ldots, N
$$

where $\mathbf{x}_{i}$ is the position vector, $\boldsymbol{\Phi}_{i}$ is the angular displacement vector, $I_{i}$ is the moment of inertia of the $i$ th particle, $\mathbf{F}_{i j}, \mathbf{M}_{i j}$ are the force and the torque experienced by the $i$ th particle from the $j$ th particle.

The summation is carried out for all $j$ particles which are in contact with the particle $i$. The force $\mathbf{F}_{i j}$ of the interaction between the $i$ th and $j$ th grains can be expanded into the normal force $\mathbf{F}_{i j}^{n}$ directed along the line connecting the centers of the two elements and the force $\mathbf{F}_{i j}^{s}$ directed perpendicularly to this line. The normal force $\mathbf{F}_{i j}^{n}$ depends nonlinearly on the relative displacement $\delta_{i j}=r_{i}+r_{j}-\sqrt{\sum_{k=1}^{3}\left(x_{i}^{k}-x_{j}^{k}\right)^{2}}$, where $r_{i}$ and $r_{j}$ are the radii of the $i$ th and $j$ th particles, the upper index denotes coordinates. According to the Hertz law [33]

$$
\mathbf{F}_{i j}^{n}=-C_{n} \delta_{i j}^{\alpha} \mathbf{n}_{i j}, \quad \alpha=3 / 2,
$$

where $\mathbf{n}_{i j}$ is the unit vector along the line connecting the centers of interacting particles; $C_{n}=$ 


\section{S. MYKULYAK, S. SKURATIVSKYI}

$\frac{\sqrt{2} E}{3\left(1-\nu^{2}\right)}\left(\frac{1}{r_{i}}+\frac{1}{r_{j}}\right)^{-1 / 2}, E$ is Young's modulus, and $\nu$ is Poisson's ratio.

The tangential force $\mathbf{F}_{i j}^{s}$ depends on the relative shear along the line perpendicular to the vector $\mathbf{n}_{i j}$ :

$$
\mathbf{F}_{i j}^{s}=-C_{f} \frac{\mathbf{w}_{i j}^{s}}{w_{i j}^{s}} F_{i j}^{n},
$$

where the relative transverse velocity $\mathbf{w}_{i j}^{s}$ of the $i$ th and $j$ th spherical particles is defined as follows [34]

$$
\begin{aligned}
\mathbf{w}_{i j}^{s} & =\mathbf{v}_{i}-\mathbf{v}_{j}-\mathbf{n}_{i j}\left(\mathbf{v}_{i}-\mathbf{v}_{j}, \mathbf{n}_{i j}\right) \\
& +\left(\frac{\delta_{i j}}{r_{i}+r_{j}}-1\right)\left(\mathbf{r}_{i} \boldsymbol{\omega}_{i}+\mathbf{r}_{j} \boldsymbol{\omega}_{j}\right) \mathbf{n}_{i j}
\end{aligned}
$$

$\mathbf{v}_{i}$ and $\boldsymbol{\omega}_{i}$ are the linear and angular velocities of the $i$ th particle, and $C_{f}$ is the friction coefficient.

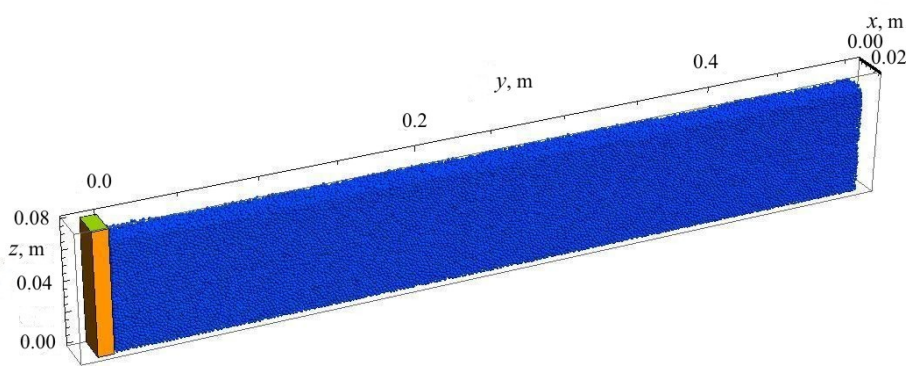

(a)

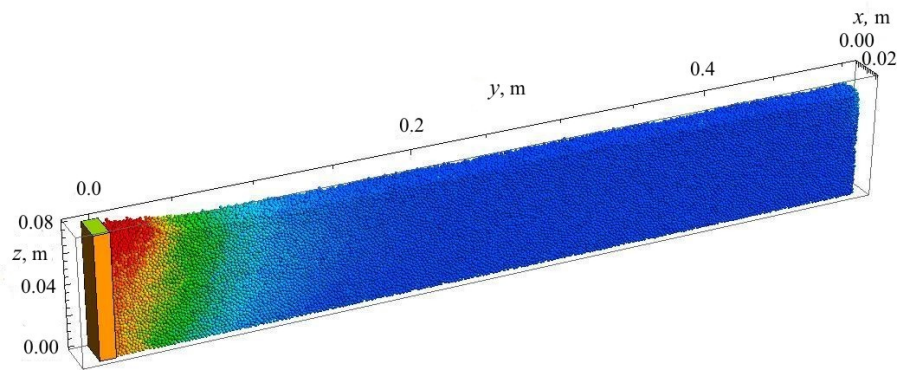

(b)

Fig. 1. The granular layer subjected to the impulse load $F$ at the initial time $t=0$ (a) and at $t=10 \mathrm{~ms}$ (b)

The particles comprising the granular medium interact with exterior walls (piston, bottom and back wall) elastically and the corresponding force is written according to the Hertz law for a sphere interacting with a plane $\left(r_{j} \rightarrow \infty\right)$. The system of equations (1) is solved numerically using the velocity Verlet algorithm [35]. The accuracy of calculations using this method reaches the order of $O\left(t^{3}\right)$ [36]. The following constants specifying forces are $E=50 \mathrm{GPa}, \nu=0.25, C_{f}=0.1$. The density of the particles' material is $\rho=2500 \mathrm{~kg} / \mathrm{m}^{3}$. These parameters correspond to the average values for sand grains. The granular layer consists of spheres with the Gaussian size distribution having the mean radius $r_{0}=1 \mathrm{~mm}$ and variance $d=10^{-4} \mathrm{~mm}^{2}$. The total number of particles is $N=10^{5}$.

To simulate the dynamics of the granular layer, the initial and boundary conditions for the system (1) should be prescribed. At first, to prepare the granular layer, spheres with zero velocities and randomly distributed in the sample having dimensions $L_{x}=0.02 \mathrm{~m}, L_{y}=0.5$ $\mathrm{m}$, and $L_{z}=0.8 \mathrm{~m}$ are chosen. Then they are exposed to the influence of the external gravitational field till a steady state is reached. The resulting particle configuration shown in Fig. 1a is considered as the initial conditions for the system (1). All three sizes of the granular sample are much larger than the size of the grains. This allows the formation of full-fledged threedimensional wave structures.

The perturbation of the granular layer is provided by an elastic piston subjected to the force $F$

$$
F= \begin{cases}F_{0} \sin ^{2}\left(\pi t / t_{0}\right) & \text { if } t \leq t_{0}, \\ 0 & \text { if } t>t_{0},\end{cases}
$$

where $F_{0}=1000 \mathrm{~N}, t_{0}=1 \mathrm{~ms}$.

The main aim of the simulations is to study the collective particle dynamics. In particular, our focus is on the correlated states formation, their revealing and properties. To characterize the velocity field, one can introduce the quantity

$$
V_{a k}=\frac{1}{n} \sum_{i=1}^{n} v_{k}^{i}, \quad k=\{x, y, z\},
$$

where $v_{k}^{i}$ are the $k$ th components of the velocities of the particles lying in the cube of edge length $l=5 \mathrm{~mm} ; n$ is the number of particles in the cubic area. It is evident that, for instance, $V_{a x}$ coincides with the mean value of $x$-components of the velocities of the particles located in the specified cube. The cubes are located 
at nine distances from the origin and at three heights $z=10,35,60 \mathrm{~mm}$, respectively. The average number of granules that fall into the selected area is 72 .

\section{THE RESULTS OF THE SIMULATION}

Thus, after the excitation of the granular layer by the force pulse, a wave reaching the opposite fixed layer edge in $10 \mathrm{~ms}$ is formed. Only this time interval is considered in our work. The final stage of the layer is presented in Fig. 1b illustrating the particle ejection near the piston, whereas the processes at distances larger than $\sim 0.1 \mathrm{~m}$ are not observable with the naked eye.
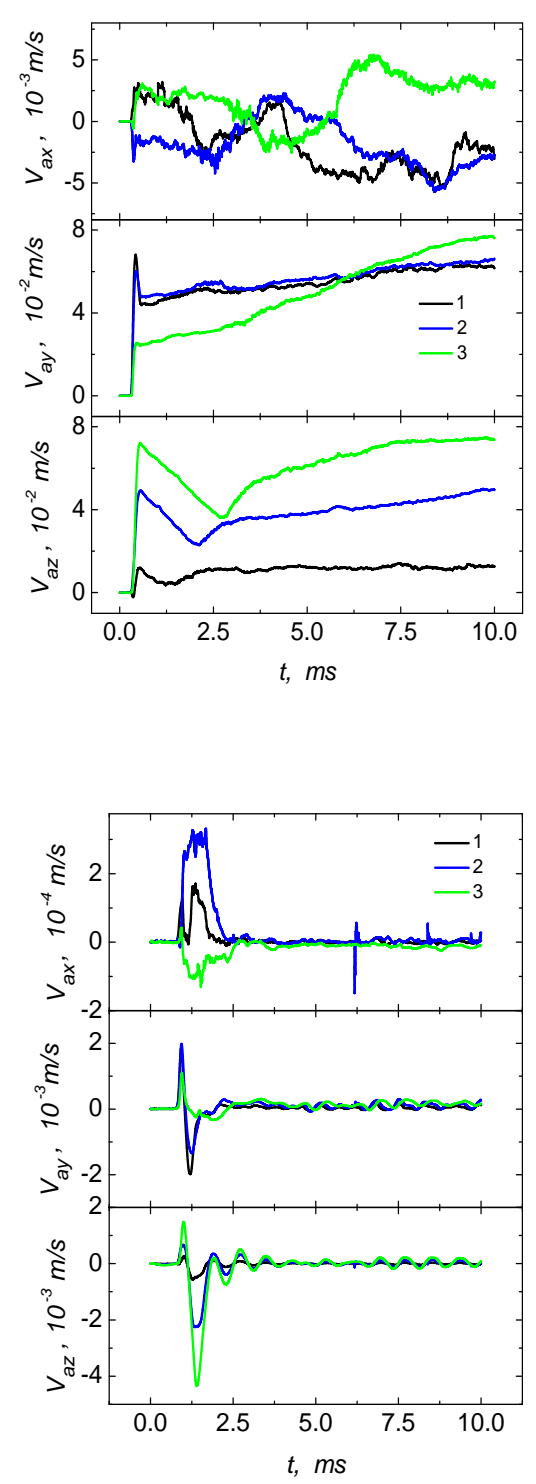

Fig. 2. Time dependencies of the average components $V_{a x}$, $V_{a y}$, and $V_{a z}$ at distance $y=0.1 \mathrm{~m}$ (top panel) and $y=$ $0.3 \mathrm{~m}$ (bottom panel) for three heights: 1) $z=10 \mathrm{~mm}, 2$ )

$$
z=35 \mathrm{~mm}, 3) z=60 \mathrm{~mm}
$$

The analysis of $V_{a k}$ derived over the cubes whose centers are located at the points $\left(L_{x} / 2 ; 0.1 ; z_{1,2,3}\right)$ demonstrates the clear wave front formation (Fig. 2, top panel). In this case, the amplitude of the component $V_{a z}$ at the upper cube even exceeds the amplitude of the component $V_{a y}$. In the direction perpendicular to the wave propagation there are chaotic perturbations of the component $V_{a x}$ that almost do not correlate with the other two. The magnitude of these perturbations is an order of magnitude smaller than that of the components $V_{a y}$ and $V_{a z}$. During the propagation, the wave rapidly decays and at the distance $y=0.3 \mathrm{~m}$, periodic oscillations of the components $V_{a y}$ and $V_{a z}$ occur (Fig. 2, bottom panel). Most brightly these oscillations are expressed for the component $V_{a z}$. The component $V_{a x}$ is also the order less than others, although here in the beginning there are correlations with these components. The spectra of these time dependencies are shown in Fig. 3. For the component $V_{a z}$, the frequency $\omega_{s}=600 \mathrm{~Hz}$ is clearly distinguished. In the spectra of the component $V_{a y}$, this frequency is also selected. As for the spectra of the component $V_{a x}$, there are no characteristic frequencies for any heights.

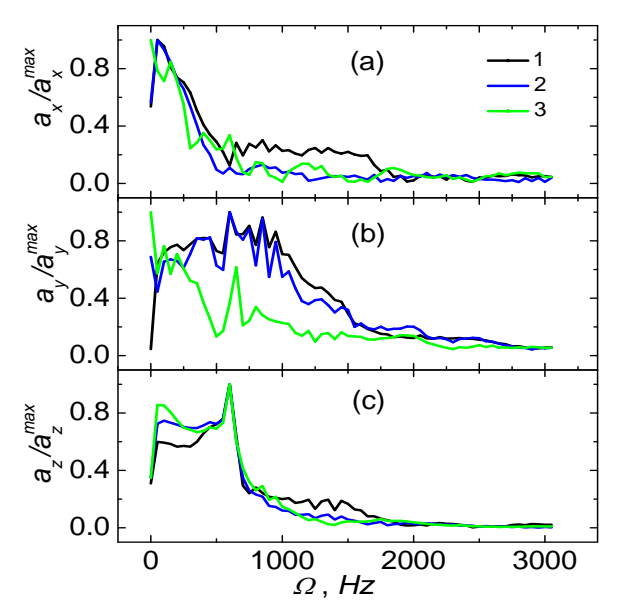

Fig. 3. Amplitude spectra $a_{x}, a_{y}$, and $a_{z}$ of the time dependencies $V_{a x}, V_{a y}$, and $V_{a z}$ at the distance $y=0.3 \mathrm{~m}$ for three heights: 1) $z=10 \mathrm{~mm}, 2) z=35 \mathrm{~mm}, 3) z=60 \mathrm{~mm}$ normalized by the maximal values $a_{x}^{\max }, a_{y}^{\max }$, and $a_{z}^{\max }$

The analysis of the velocity field shows that the motions of the material particles are coherent, i.e., the specific vortex structures similar to those in the two-dimensional case [32] are formed in this area (Fig. 4). To investigate the wave structures, we apply the correlation analysis to the velocity field. To do this, ten cubes located at the height $z=0.035 \mathrm{~m}$ along the $y$ axis $10 \mathrm{~mm}$ apart from each other are selected. As above, the size of the edges of the selected cubes is $5 \mathrm{~mm}$, and the average number of grains falling into the selected areas is 72 , respectively. For each pair of cubes, the correlation function is calculated

$$
C_{k \ell}=\sum_{i, j} v_{z}^{k i}(t) v_{z}^{\ell j}(t)
$$




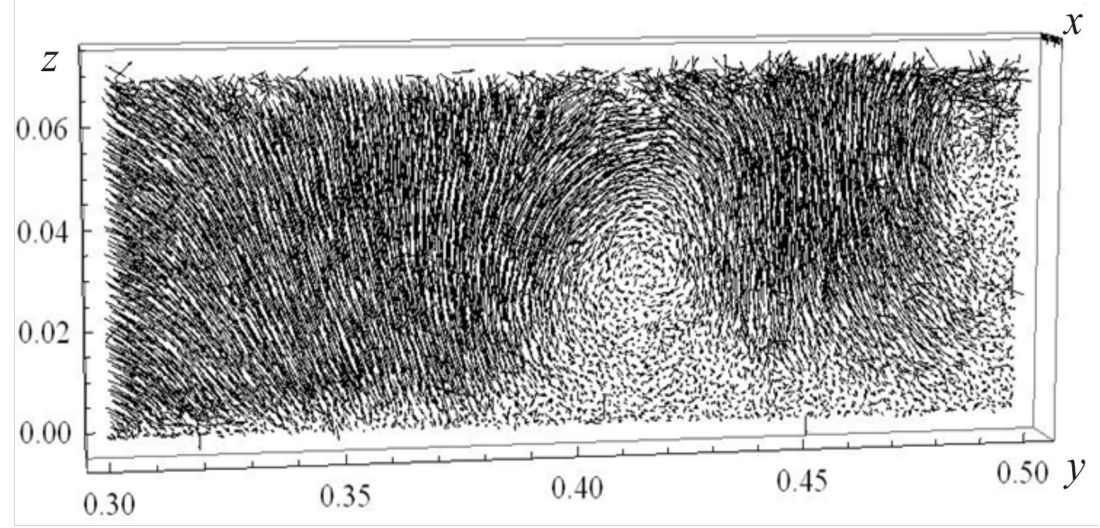

Fig. 4. Wave field in the range $0.3 \mathrm{~m} \leq y \leq 0.5 \mathrm{~m}$ at the moment $t=6.0 \mathrm{~ms}$

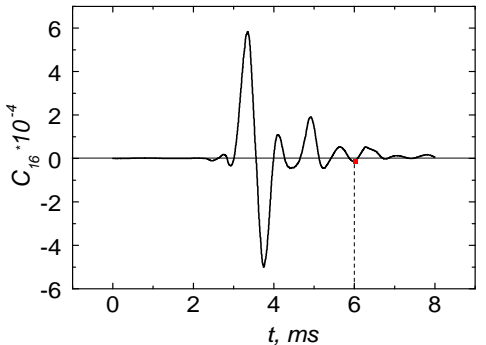

(a)

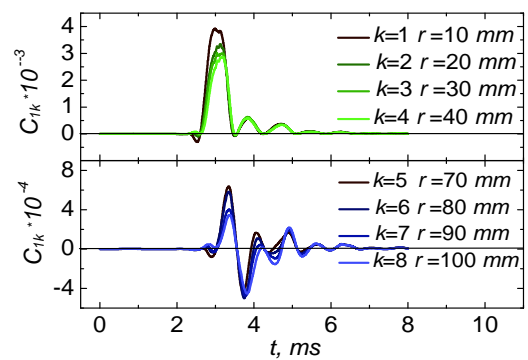

(b)

Fig. 5. The correlation functions evaluated for the grains located in : (a) the cube with the center at the point $(0,0.368$, $0.035) \mathrm{m}$ and in the cube with the center at the point $(0,0.448,0.035) \mathrm{m}$ (the circle corresponds to time $t=6.0 \mathrm{~ms}$, at which the velocity field snapshot is depicted in Fig. 4); (b) cubes whose centers are located at small $r=0.01-0.04 \mathrm{~m}$ (upper panel) and significant distances $r=0.07-0.1 \mathrm{~m}$ (bottom panel) from the specified cube located at the distance of $0.368 \mathrm{~m}$

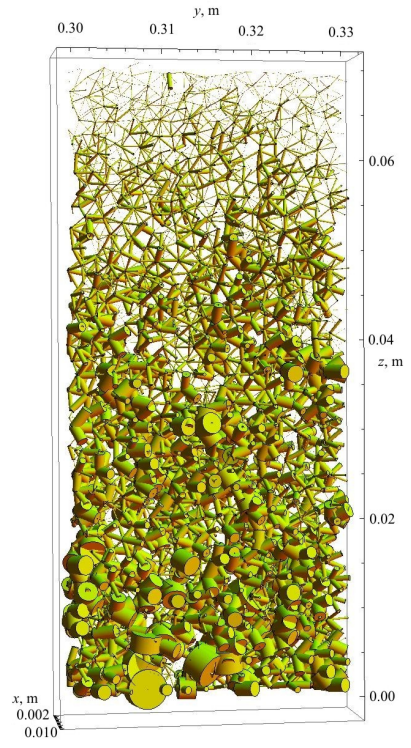

(a)

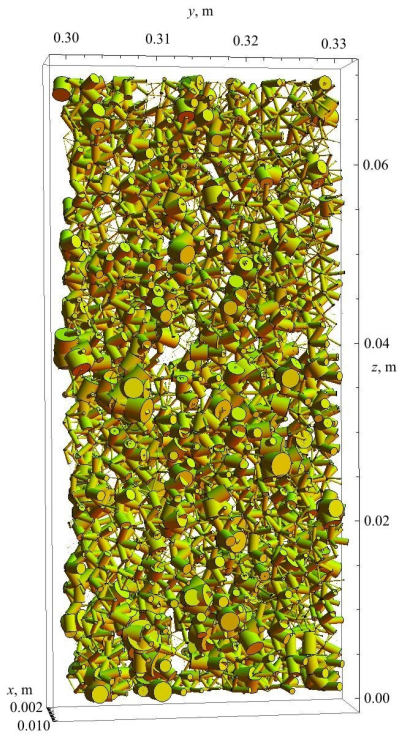

(b)

Fig. 6. The intergranular forces in layer fragments for two initial stress states: a) compressed medium, $z=72.9 \mathrm{~mm}$; b) compressed medium, $z=70.7 \mathrm{~mm} ; z$ is the coordinate of the upper wall. Here, the intergranular forces are depicted in the form of cylinders connecting the centers of the grains, and a larger force corresponds to a cylinder with a larger diameter 

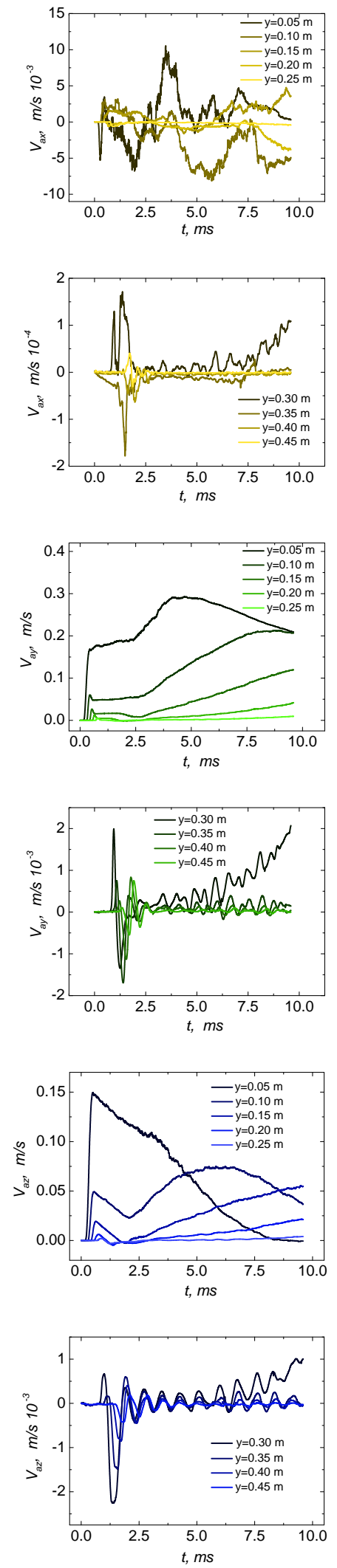

Fig. 7. Time dependencies of the averaged velocity components $V_{a x}, V_{a y}, V_{a z}$ at nine distances from the front wall. The upper wall is at a height of $z=72.9 \mathrm{~mm}$ (uncompressed medium)
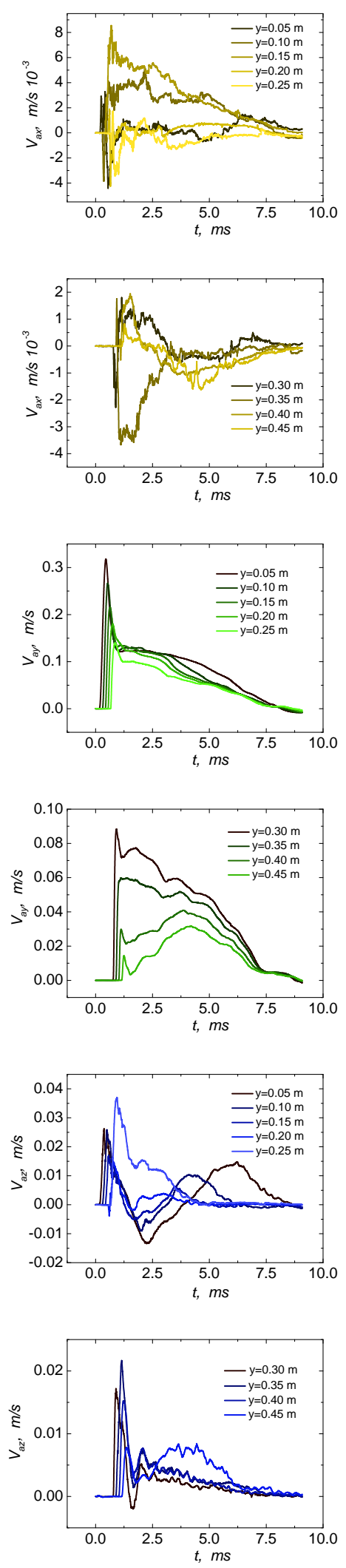

Fig. 8. Time dependencies of the averaged velocity components $V_{a x}, V_{a y}, V_{a z}$ at different distances. The upper wall is at a height of $z=70.7 \mathrm{~mm}$ (compressed medium) 
Here indexes $k$ and $\ell$ are related to the selected cubic areas and indexes $i, j$ denote the grains in the corresponding areas. Only correlations of components $V_{z}$ are studied. In the vortex structure, the grains move in opposite directions relative to the vortex center (Fig. 4); therefore the correlation functions for the areas located on different sides of the center are negative. Fig. 5a shows the time dependence of the correlation function $C_{k \ell}$ for velocities of the elements located in the selected regions to the left and to the right of the vortex presented in Fig. 4. At the moment $t=6.0 \mathrm{~ms}$, which corresponds to the vector field shown in Fig. 4, the correlation function has a negative value. Fig. 5b shows the time dependencies for the correlation functions of grains located near and over long distances. One can see that for close grains, the correlation functions have only positive values, that is, the grains move in one direction. For long-run grains, the correlation functions have both a positive and a negative value. The negative values indicate that the grains are moving in the opposite direction, and therefore the existence of vortex structures is possible at this moment.

Since there are no coherent particles' motions in the $x$ direction, the wave structures are two-dimensional and the size of the layer in the $\mathrm{x}$ direction is not decisive for the vortex characteristics

The simulations of this problem were also performed in a granular medium when friction between grains is absent. In this case, the wave structures are not formed. This fact suggests that rotation structures are connected with the rotational grain motion and energy dissipation, since no grain rotations occur in the absence of friction.

Two-dimensional simulations [32] have shown if the layer is loaded with a weight on the free surface, the wave structures are not formed and the wave attenuation is sufficiently weaker than in the medium with a free surface. The question is: do the wave structures disappear because of the loading of the layer and, consequently, the leveling of the initial gradient field of the particle interaction forces or because of a absence of the free surface? To answer this question, the three-dimension simulations of the wave propagation are performed both in a loaded granular layer and in an unloaded layer but confined by a wall on the top surface. The stressed state was created by compressing the layer with a fixed upper wall. Figure 6 a shows the initial state of the medium without the additional compression with an upper wall located on the surface of the layer at the height of $72.9 \mathrm{~mm}$. Fig. $6 \mathrm{~b}$ illustrates the compressed medium with an upper wall at the height of $70.7 \mathrm{~mm}$. The medium in Fig. $6 \mathrm{~b}$ is compressed by the upper wall so that it can be neglected by the gradient due to gravity.
Figure 7 shows the time dependences of all three velocity components in the case of an uncompressed medium, and Fig. 8 for a compressed medium. Figure 7 , clearly demonstrates that the upper wall does not interfere with the formation of wave structures. The oscillations connected with the wave structures are particularly clearly recorded for the vertical component of the average velocity in the area $y>0.3 \mathrm{~m}$. For a compressed medium, such periodic oscillations are absent (Fig. 8). In the uncompressed and uncovered layer, the attenuation of the wave is close to that in the uncovered layer. This is true for all components of mass velocity. In the compressed layer, only $V_{a y}$ component attenuates, but this attenuation is many times smaller than in the case of the uncompressed layer. As for components $V_{a x}$ and $V_{a z}$, they do not attenuate at all.

\section{SUMMARY AND CONCLUSIONS}

The numerical simulation of the three-dimensional wave process in a layer of a granular medium consisting of spherical grains in a gravity field demonstrates that as in the case of the two-dimensional problem, the shock-generated wave quickly attenuates, and then vortex structures are formed. It turned out that the vertical velocity component in these structures may exceed the velocity in the wave propagation direction. As for the velocity component in the direction perpendicular to the wave propagation direction, it is chaotic and its magnitude is much smaller than the other two components. The use of correlation analysis made it possible to determine the position, moment of origin and duration of the existence of wave structures. Wave structures can be formed only if there is friction between grains and hence there are rotation motions of the grains. Another necessary condition for forming wave structures is the existence of heterogeneity of the stress field. Here the heterogeneity is created by the gravitational field. The rotation structures can be regarded as dissipative structures providing the manifestation of self-organizing properties of granular media.

\section{Acknowledgements}

This research has been supported in part by the National Academy of Sciences of Ukraine, grant \#0118U000044.
[1] H. M. Jaeger, S. R. Nagel, Science 255, 1523 (1992); https://doi.org/10.1126/science. 255.5051.1523.

[2] H. M. Jaeger, S. R. Nagel, Rev. Mod. Phys. 68, 1259 (1996); https://doi.org/10.1103/RevModPhys.6 8.1259.
[3] A. Mehta, Granular Physics (Cambridge University Press, Cambridge, 2007).

[4] B. Andreotti, Y. Forterre, O. Pouliquen, Granular Media: between Fluid and Solid (Cambridge University Press, Cambridge, 2013). 
[5] V. A. Danylenko, S. V. Mykulyak, V. O. Polyakovskyi, V. V. Kulich, I. I. Oleynik, Phys. Rev. E. 96, 012906 (2017); https://doi.org/10.1103/PhysRevE.9 6.012906.

[6] S. V. Mykulyak, V. O. Polyakovskyi, S. I. Skurativskyi, Pure Appl. Geophys. 176, 4309 (2019); https://doi.or g/10.1007/s00024-019-02209-0.

[7] C. H. Liu, S. R. Nagel, Phys. Rev. Lett. 68, 301 (1992); https://doi.org/10.1103/PhysRevLett.68.2301.

[8] C. H. Liu, S. R. Nagel, Phys. Rev. B 48, 15646 (1993); https://doi.org/10.1103/PhysRevB.48.15646.

[9] C. H. Liu, S. R. Nagel, J. Phys.: Condens. Matter 6, A433 (1994); https://doi.org/10.1088/0953-8984/6/ $23 \mathrm{~A} / 071$.

[10] X. Jia, C. Caroli, B. Velicky, Phys. Rev. Lett. 82, 1863 (1999); https://doi.org/10.1103/PhysRevLett. 82.1863 .

[11] E. T. Owens, K. E. Daniels, Europhys. Lett. 94, 54005 (2011); https : //doi.org/10.1209/0295-5075/94 /54005.

[12] S. R. Hostler, C. E. Brennen, Phys. Rev. E 72, 031303 (2005); https://doi.org/10.1103/PhysRevE.7 2.031303.

[13] J. Anfosso, V. Gibiat, Europhys. Lett. 67, 376 (2004); https://doi.org/10.1209/epl/i2004-10085-9.

[14] X. Jia, Phys. Rev. Lett. 93, 154303 (2004); https://do i.org/10.1103/PhysRevLett.93.154303.

[15] E. Somfai, J. N. Roux, J. H. Snoeijer, M. van Hecke, W. van Saarloos, Phys. Rev. E 72, 021301 (2005); https: //doi.org/10.1103/PhysRevE.72.021301.

[16] V. N. Nikolaevskiy, Geomechanics and Fluidodynamics: With Applications to Reservoir Engineering. Ser.: Theory and Applications of Transport in Porous Media 8 (Springer, Netherlands, 1996).

[17] B. Velický, C. Caroli, Phys. Rev. E 65, 021307 (2002); https://doi.org/10.1103/PhysRevE.65.021307.

[18] H. A. Makse, N. Gland, D. L. Johnson, L. Schwartz, Phys. Rev. E 70, 061302 (2004); https://doi.org/10.1 103/PhysRevE.70.061302.

[19] O. Mouraille, W. A. Mulder, S. Luding, J. Stat. Mech. 7, P07023 (2006); https://doi.org/10.1088/1742-546 8/2006/07/P07023.

[20] O. Mouraille, S. Luding, Ultrasonics 48, 498 (2008); ht tps://doi.org/10.1016/j.ultras.2008.03.009.
[21] V. F. Nesterenko, Dynamics of Heterogeneous Materials (Springer-Verlag, New York, 2001); https://doi.org/ 10.1007/978-1-4757-3524-6.

[22] S. Sen, M. Manciu, R.S. Sinkovits, A. J. Hurd, Granul. Matter 3 (2001) 33-39; https://doi.org/10.1007/s 100 350000067.

[23] S. Job, F. Melo, A. Sokolow, S. Sen, Granul. Matter 10, 13 (2007); https://doi.org/10.1007/s10035-007-005 4- 2 .

[24] A. P. Awasthi, K. J. Smith, P. H. Geubelle, J. Lambros, Mech. Materials 54, 100 (2012); https ://doi.org/10.1 016/j.mechmat. 2012.07.005.

[25] A. Leonard, F. Fraternali, C. Daraio, Exp. Mech. 53, 327 (2013); https://doi.org/10.1007/s11340-011-9 $544-6$.

[26] M. Manjunath, A. Awasthi, P. Geubelle, Physica D 266, 42 (2014); https://doi.org/10.1016/j.physd.2013.1 0.004 .

[27] A. Awasthi, Z. Wang, N. Broadhurst, P. Geubelle, Granular Matter 17, 21 (2015); https://doi.org/10.1 007/s10035-015-0547-3.

[28] P. Evesque, J. Rajchenbach, Phys. Rev. Lett. 62, 44 (1989); https://doi.org/10.1103/PhysRevLett.62 .44 .

[29] C. Laroche, S. Douady, S. Fauve, J. Phys. France 50, 699 (1989); https://doi .org/10.1051/jphys : 01989005 007069900.

[30] J. Knight et al., Phys. Rev. E 54, 5726 (1996); https: //doi.org/10.1103/PhysRevE.54.5726.

[31] C. R. Wassgren Jr., Ph.D. thesis (California Institute of Technology, 1997)

[32] S. V. Mykulyak, Phys. Mesomech. 17, 157 (2014); http s://doi.org/10.1134/S1029959914020088.

[33] L. D. Landau, E. M. Lifshitz, Elasticity Theory (Pergamon Press, Oxford, 1975).

[34] H.J. Herrmann, S. Luding, Continuum Mech. Thermodyn. 10, 189 (1998); https://doi.org/10 $.1007 / \mathrm{s} 001610050089$.

[35] W. C. Swope, H. C. Andersen, P. H. Berens, K. R. Wilson, J. Chem. Phys. 76, 637 (1982); https://doi.org/ 10.1063/1.442716.

[36] Q. Spreiter and M. Walter, J. Comput. Phys.152, 102 (1999); https://doi.org/10.1006/jcph.1999.6237.

\title{
НЕЛІНІЙНА ХВИЛЬОВА ДИНАМІКА ДИСПЕРСНОГО ГРАНУЛЬОВАНОГО ШАРУ, ЗУМОВЛЕНА РУХОМИМ ПОРШНЕМ
}

\author{
С. В. Микуляк, С. І. Скуратівський \\ Інститут геофізики ім. С. I. Субботіна НАН Украӥни, \\ вул. Богдана Хмелвницького, 63Б, Київ, 03142, Украӥна
}

$\mathrm{Y}$ роботі методом дискретних елементів змодельовано тривимірне поширення нелінійної хвилі в шарі гранульованого середовища, що перебуває в полі сили тяжіння. Гранули мають форму куль, а їхні розміри розподілені за законом Гаусса з невеликою дисперсією. Взаємодію між гранулами описано законом Герца з урахуванням сухого тертя Кулона. Хвиля генерується поршнем, що зазнає дії імпульсного навантаження. Верхня поверхня шару вільна. Систему рівнянь, що описує рух гранул, розв'язано числовим методом із використанням алгоритму Верле у швидкісній формі.

Числові розрахунки показали, що початкове збурення зазнає сильного згасання та формування у процесі еволюції хвильових вихрових структур. З'ясовано, що вертикальна компонента швидкості в цих структурах може перевищувати швидкість у напрямку поширення хвилі. Інший складник швидкості, перпендикулярний до напрямку поширення хвилі, має хаотичний характер і його величина значно менша за інші.

Положення, момент виникнення та тривалість існування вихрових структур визначено за допомогою методів кореляційного аналізу. Ці структури можуть утворюватися лише за умови тертя між 
гранулами. Ще однією необхідною умовою формування вихрових структур є неоднорідність поля напружень, яка в цій постановці зумовлена гравітаційним полем. Керували полем напружень у шарі гранульованого середовища за допомогою навантаження на верхню невагому жорстку стінку.

Якщо стінка не змінює неоднорідності, викликаної гравітаційним полем, то вона не перешкоджає утворенню вихрових структур.

Зростання навантаження на верхню стінку руйнує неоднорідність, створену гравітаційним полем, і це спричиняє зникнення хвильових структур. При цьому згасання початкового збурення стає значно повільнішим.

Виявлені вихрові утворення можна розглядати як дисипативні структури, що забезпечують прояв самоорганізуючих властивостей гранульованих середовищ.

Ключові слова: гранульоване середовище, нелінійні хвилі, вихрові хвильові утворення. 